\title{
Utilisation of ICTs as Teaching Aids in Two Higher Education Institutions in Lagos
}

\author{
Adesoji A. Oni ${ }^{1,}{ }^{*}$, Esther Samuel Uko ${ }^{2}$ \\ ${ }^{1}$ University of Lagos [* Corresponding author: aoluoni@yahoo.com], ${ }^{2}$ University of Calabar
}

\begin{abstract}
Modern information and communication technologies (ICTs) are recognised as having enormous potential for improving quality in higher education delivery and, subsequently, contributing to production of graduates who are suited to the needs of the contemporary labour market. This recognition has formed the basis for investment in the development of ICT capacity in higher education institutions (HEIs) in Nigeria. After years of this investment, this study investigated the reach and utilisation of ICT facilities in HEIs in the country. The findings were that availability of ICT facilities, notably mobile phones and the internet, is widespread. However, these have not been mainstreamed into teaching and learning processes. This is blamed on gaps in funding and training. Recommendations for the better deployment of ICT as an aid in teaching are made.
\end{abstract}

Keywords: ICT; Teaching and learning; Curriculum innovation.

\section{$1 \quad$ Introduction}

ICT has been described as a powerful tool that enables educational change and reform (Blurton, 1999). While we recognize that the use of instructional technology in the higher education teaching and learning processes is still in its infancy in Nigeria, ICT instructional use is vital to the progress and development of faculty and students alike. HEIs, especially those in the west, have adopted ICT as a means to impart upon students the knowledge and skills demanded by 21 st century educational advancement (UNESCO, 2002). The role of ICT in the teaching and learning process is not in doubt. The widespread availability of ICTs has led to the globalization process and continues to have a large influence on social, economic, political and cultural structures around the world. Today's world is interconnected and the value of this interconnectivity 
cannot be overemphasized. The ICT capabilities of a nation to some extent determine its performance in all ramifications especially in global sociopolitical activities, education, health and socio-cultural playing field of the $21 \mathrm{st}$ century. These technologies have been incorporated in the daily activities of the Western World including the educational sector. These same technologies have however found expression in the developing countries.

In Nigeria, ICT is an experiment in progress. The importance of ICTs in education can be described as a basic tool to achieving a better standard in our academic community. ICT enhances improved access to learning, developed higher education and establishing a viable learning environment (Kaino, 2006). ICTs are increasingly utilized by higher education institutions worldwide. They are emerging as a part of on-campus delivery as well as open and distance learning modalities. UNESCO actions in this area focus on assisting Member States to develop robust policies in ICTs and higher education. (UNESCO 2010)

In furtherance, ICTs in higher education are being used for developing course material; delivering and sharing content; communication between learners, teachers and the outside world; creation and delivery of presentations and lectures; academic research; administrative support, student enrolment. Higher education institutions in developing countries are on the whole making the most of computers and software available to them even though challenges including insufficient telephone and telecommunication infrastructures, lack of training resources for teachers, and lack of skilled and experienced information technology specialists to assist with development, maintenance and support of ICT usage in higher education institutions (HEIs) remain. ICT in our higher institutions today are being used for administration and instruction through the use of portals to enable students to apply for admission and to guide them in the dissemination of information (Imouokhome, Omwangbe \& Ifediora, 2007)

Felicity 2006 notes that ICTs are thought to bring a greater flexibility to everyday activities. One can shop, work and learn from the comfort of one's own home. This is an attribute especially important to the issues explored in this research because it may enable education to begin immediately, rather than being dependent on the construction of school buildings. Although, it has its pitfalls; ICTs could offer greater access to more information. In terms of providing more information, the internet is an example of how people can now access, almost instantaneously information from the other side of the world. In terms of greater access ICTs could remove the need to travel to another location in order to learn or work, or on the contrary, mobile technology allows the work place to move more easily. Whilst this concept may just be a luxury in the developed world, in the developing world, it may be more essential. For example, in a war zone, mobility is restricted, often prohibiting people from 
going to work or school, this could be circumvented by bringing the work to the people.

The rapid growth of ICTs has challenged the traditional method of teaching and changed the educational landscape globally. The teaching method is now divided into two different ways of thinking on education, one is traditional and other one is ICT method. Most of the teachers and experts in some developing and developed nations have explored new methods of teaching and believe that modern methods or the ICT method is better than the traditional method of teaching. The traditional role of teaching focuses on the teacher as organizers of learning activity, providers of information and experts of knowledge. The teacher carries too much of responsibility for teaching in the classroom to make sure everything they are teaching is understood by the students or we can say there is a typical way to control class where the teacher teaches using blackboard, explains concepts, asks students to copy and makes sure that students are paying attention. (Rawandale et al., 2013). The traditional way also focuses on inculcating discipline among students and building their character. The emergence and the growth of ICTs has challenged the teachers' way of thinking and changed the educational landscape globally. Use of ICT in teaching develops higher order skills such as collaborating across time and place and solving complex real world problems (Bottino, 2003; Mason, 2000; Lim \& Hang, 2003). It improves the students' perception and understanding of the world. Thus, ICT can be used to prepare the workforce for the information society and the new global economy (Kozma, 2005). There are at least two fundamental reasons that justify the use of ICT. The first is that university education has a responsibility to ensure the future graduates. The second reason is that ICT may contribute to more and better learning (Francesc, 2005).

It is now widely accepted that the new method (ICT) is the best way to obtain attention of the new generation of students and make them interested in subjects. The ICT method also helps the students get actively involved through hand on activities rather than teaching them by traditional method. The role of teacher has changed now. According to the new role, a teacher is now treated as an advisor, manager and facilitator of learning and also as a developer of skills. The use of ICT method develops the student teacher relationship, where the teacher acts as an observer; standing back to let learning happen and lets the students solve problems. In this case, the teacher is responsive to students' cognitive needs and development.

The ICT is used in modern teaching to promote interaction, support creativity, active learning, high order thinking etc. While we recognize that the use of instructional technology in the higher education teaching and learning processes is still in its infancy in Nigeria, ICT instructional use is vital to the progress and development of faculty and students alike. Higher education institutions, especially those in the west, have adopted ICT as a means to impart 
upon students the knowledge and skills demanded by 21 st century educational advancement (UNESCO, 2002a). According to UNESCO (2002b), ICT now permeates the education environment and underpins the very success of $21 \mathrm{st}$ century education. ICT also adds value to the processes of learning and to the organization and management of learning institutions. Technologies are a driving force behind much of the development and innovation in both developed and developing countries. As such, all countries must seek to benefit from technological developments. To be able to do so, professionals (including faculty) have to be educated with sound ICT backgrounds, independent of specific computer platforms or software environments, to meet the required competencies of the ever-changing global environment.

When ICT in education does not achieve expected goals or when it introduces complicated educational reforms, students and teachers can lose focus on the essentials and become distracted by the rapidly changing technologies themselves. This result is likely when students and teachers have not been able to acquire a full understanding of the technologies, the role ICT plays and where, how and what technology to use. When the meaning of ICT and its unlimited potential in the educational arena are understood, rapidly changing technologies are not seen as overwhelming, but as enablers of greater critical thinking and problem solving in education (Iloanusi \& Osuagwu, 2009). The use of ICT in the educational system is remarkable especially among the teachers, this is what gave birth to multi-dimensional learning approach through distance learning education which has been adopted in many schools in the developed and developing countries to cater for the distance waged and unwaged students (Bartololic-Zlomislic \& Bates, 1998). The advantages of ICT is shown in different angles and has encouraged the learning process, it has also enable access to learning by all while creating a conducive environment, encouraging viable knowledge delivery and quick answers to many questions bothering the teachers and the students.( Kaino, 2006). ICT can also be operated through the term called:

Isaac (2007) defined e-education as entailing more than developing computer literacy. He stated that it is the ability to apply ICTs, access, analyse, evaluate, integrate, present, and communicate information; create knowledge and information by adapting, applying, designing, inventing, and authoring information; and function in a knowledge society by using appropriate technology and mastering communication and collaboration skills.

Lenhart and Madden (2005) referred to young people as the 'generation Google' or digital natives because Young people use technology not just for communication and consuming information, but also for creating and sharing knowledge. Greenhill, 2008 also noted that Internet-based service are becoming an important part of many aspects of users' lives cutting across socialising, study and work. Obviously ICT skills can impact on employment opportunities 
in the software and hardware industries (ILO, 2001; Expert Group on Future Skill Needs, 2008). However, as Bradbrook (2008) indicate, there are many other ways in which ICT can increase the employability of young people:

1. Development of softer skills such as networking, collaboration and problem-solving (these skills can also be developed by gaming);

2. Through use of social and cultural tools for sharing information and experiences through peer-to-peer networking and communities of interest, especially for isolated rural young people;

3. Engendering greater social diversity in schools by enabling communication and cooperation through virtual and real linkages with other schools in different geographic and socio-economic environments;

4. Supporting disadvantaged members of minority groups, particularly those with concealable stigmatised identities;

5. Through provision of confidential support and advice; this is especially important for challenges such as health, bullying and crime; and

6. Through supporting political activities.

ICT skills are not only required for jobs in the ICT sector. The demand for them cuts across sectors and job types. ICT skills are increasingly important in sectors such as agriculture, construction, education, and service industries. In many labour markets, ICT-related occupations represent an important slice of economic activity (Lopez-Bassols, 2002; Van Welsum \& Vickery, 2005). The diffusion of ICTs across all economic sectors is placing new demands on workers' skills. The changing skill set is both expanding employment opportunities and imposing new demands on disadvantaged groups. In today's job market, basic ICT skills are considered essential for people entering the workforce and for those trying to grow. Governments consider an ICT skilled workforce a strategic asset that spurs economic growth, promotes competitiveness, and improves business productivity. A nation's economic well-being depends "on both the effective use of ICT for businesses and industrial processes and on the knowledge, competencies, and skills of current and new employees" (European Commission, 2004, p. 2).

As Nigeria is striving hard to play a leadership role in Africa, there is an urgent need to pay attention to the improvement of teaching and learning particularly in HEIs. The youth disproportionately suffer from the malaise of unemployment. The scale of the problem is immense, holding back economic growth while stifling the aspirations of people recently entering the workforce. The causes of this situation are multifaceted and manifest differently in each region. Noting that ICT competency offers advantages in the area of youth employment, this study set out to investigate the deployment of these technologies in teaching at two HEIs in Lagos. The study undertook to respond to the following research questions: 
1. To what extent are ICT facilities available for teaching in Nigeria Higher institutions?

2. To what extent are students exposed to ICT facilities?

3. What ICT facilities do students use most?

The study adopted a survey design. Data was collected using a selfadministered questionnaire. The questionnaire was distributed to a random sample of 120 students who were drawn from two HEIs in Lagos. The data obtained were analysed using frequency counts, percentages, means and standard deviation.

\section{$2 \quad$ Findings}

\subsection{Availability of ICT Facilities}

The findings on the availability of ICT facilities in the HEIs are summarised in Table 1.

Table 1: ICT Facilities available in Nigeria Tertiary Institutions (\%, $N=120)$

\begin{tabular}{|c|c|c|c|c|c|}
\hline & Agree & Disagree & Total & $\mathrm{X}$ & St.d \\
\hline My school has a computer laboratory & 87.5 & 12.5 & 100 & 1.12 & 0.332 \\
\hline $\begin{array}{l}\text { Internet facilities are available for use at my } \\
\text { school }\end{array}$ & 68.3 & 31.7 & 100 & 1.32 & 0.467 \\
\hline $\begin{array}{l}\text { I learn through the use of computer projector at } \\
\text { my school }\end{array}$ & 45.0 & 55 & 100 & 1.55 & 0.500 \\
\hline $\begin{array}{l}\text { Teaching with the aid of ICT facilities is more } \\
\text { common in my school than any other teaching } \\
\text { method }\end{array}$ & 32.5 & 67.5 & 100 & 1.67 & 0.470 \\
\hline My faculty has internet facilities for teaching & 55.8 & 44.2 & 100 & 1.44 & 0.499 \\
\hline $\begin{array}{l}\text { My department has internet facilities for } \\
\text { teaching } \\
\text { Weighted average : } 1.32\end{array}$ & 39.2 & 60.8 & 100 & 1.61 & 0.490 \\
\hline
\end{tabular}

Table 1 shows that $87.5 \%$ of the participants reported that they have a computer laboratory in their school, of which $68.3 \%$ testify that internet is available for use at their school. A little above average (55\%) of the participants confirmed use of computer projectors for learning in their institution. Up to $67.5 \%$ of the participants "disagreed" that teaching with the aid of ICT facilities is more common in their school than any other teaching method, of which 55.8\% attested to the fact that their faculty has internet facilities for teaching. 


\subsection{Exposure to ICT Facilities}

The findings on students' exposure to ICT facilities are shown in Table 2.

Table 2: Exposure of students to ICT facilities (\%, $N=120)$

\begin{tabular}{|c|c|c|c|c|c|c|c|}
\hline & Often & Occasionally & Rarely & Never & Total & $\mathrm{x}$ & St.D \\
\hline I always access the internet & 74.2 & 20.0 & 4.2 & 1.7 & 100 & 1.33 & .640 \\
\hline $\begin{array}{l}\text { I get information from the } \\
\text { internet }\end{array}$ & 81.7 & 15.8 & 1.7 & 0.8 & 100 & 1.22 & .505 \\
\hline $\begin{array}{l}\text { I communicate with friends } \\
\text { through the internet }\end{array}$ & 70.8 & 21.7 & 5.0 & 2.5 & 100 & 1.39 & .702 \\
\hline $\begin{array}{l}\text { I use internet for educational } \\
\text { purposes }\end{array}$ & 71.7 & 20.0 & 6.7 & 1.7 & 100 & 1.38 & .688 \\
\hline I use ICT facilities for sports & 11.7 & 18.3 & 50.0 & 20.0 & 100 & 2.78 & .900 \\
\hline I chat on the internet & 65.8 & 20.0 & 5.0 & 9.2 & 100 & 1.58 & .950 \\
\hline $\begin{array}{l}\text { I find it easier to express my } \\
\text { discomfort using ICT facilities } \\
\text { Weighted average }: 1.22\end{array}$ & 45.8 & 26.7 & 17.5 & 10.0 & 100 & 1.92 & 1.017 \\
\hline
\end{tabular}

Table 2 shows that most (74.2\%) of the participants have access to the internet. The participants indicated that they "often" use ICT facilities. Majority $(81.7 \%)$ of the respondents reported that they get information from the internet. However, $70.8 \%$ used the internet to communicate with their friends and $71.7 \%$ used it for educational purposes. Only a few (11.7\%) of the respondents reported using ICT for sports. Some (45.8\%) reported that they used ICT facilities often to express their discomfort to their friends.

\subsection{Utilisation of ICT Facilities}

Table 3 shows the findings on the ICT facilities that the respondent used most frequently.

Table 3: Most frequently used ICT facilities (\%, $N=120)$

\begin{tabular}{llllll}
\hline & Yes & No & Total & X & St.D \\
\hline A desktop computer & 45 & 55 & 100 & 1.55 & .500 \\
A laptop & 70.8 & 29.2 & 100 & 1.29 & .456 \\
A mobile phone & 91.7 & 8.3 & 100 & 1.08 & .278 \\
An I-pad & 18.3 & 81.7 & 100 & 1.82 & .389 \\
A palmtop & 9.2 & 90.8 & 100 & 1.91 & .290 \\
A projector & 9.2 & 90.8 & 100 & & \\
\hline
\end{tabular}


Table 3 shows that mobile phones were the most commonly used ICT facilities with $91.7 \%$ of the participants reporting that they used them. These were followed by laptops and desktop computers.

\section{Discussion, Conclusion and Recommendations}

Ololube, Ubogu \& Egbezor (2007) identified poor ICT penetration and usage among Nigerian higher education practitioners, inadequacy of basic ICT infrastructures; lack of electricity to power the ICT materials and poor telecommunication facilities. This lack of access to much needed infrastructure is as a result of insufficient funds. Similarly, Ogunleye (2007) stated that poor power supply, lack of technical support, lack of computer laboratory/ ICT resource room were the major factor affecting the effective usage of ICT facilities in Schools.

The study of Yusuf, Afolabi and Loto (2013) analysed the constraints to effective utilization of ICT to teaching in Nigerian HEIs and reiterated that there have been a number of factors affecting the utilisation of ICT in education across the country. Such factors include inadequate funding to support the purchase of the ICT facilities, lack of training in the use of ICT facilities, teaching personnel's lack of motivation and the need among teachers to adopt ICT as teaching tools. Inadequate computer trained and certified teachers, poor funding, irregular power supply, cost of equipment and lack of relevant software and recommended that adequate funds must be provided to initiate, develop, promote, review and implement ICT policies in the educational sector to bring about an improvement in ICT utilisation.

The result of the findings revealed that, even though there is availability of ICT facilities in HEIs, the use of ICT as a means of teaching remains low. The research revealed that participants mainly use ICT to get information for their studies and some other activities but not as learning aids in class (cf. Table 2). This finding rhymes well with Castel (2000) and Yusuf, Afolabi, and Loto, (2013) among others. Among the ICT facilities that the participants used, mobile phones were the commonest. An absence of ICT instructional materials, ineffective policy implementation and a lack of other resources (infrastructures) to aid teaching and learning are responsible for shortcomings in the effective implementation of ICT in education. The study further revealed that experience makes it easier to employ and exhibit greater proficiency when using ICT instructional materials in the teaching and learning process. It was, therefore, recommended that:

1. Teachers should be given adequate training on the use of ICT for effective teaching in Nigerian higher institution.

2. ICT should be made a priority and be made available at all levels of Nigerian education system. 
3. The university management should collaborate with ICT organizations and manufacturers of ICT aids that have investments within the country.

4. Computer laboratories should be made available and well equipped while teachers should interact more with ICT resources towards skills acquisition.

5. The Government should spend more on ICT as teaching aids in the classroom while lecturers in university should encourage e-lectures for students.

\section{References}

Bottino, R. M. (2003). ICT, National policies, and impact on schools and teachers' development. CRPIT '03: Proceedings of the 3.1 and 3.3 working groups' conference of the International Federation for Information Processing, Australian Computer Society, Darling Hurst, Australia, 3-6.

Bradbrook, G. et al. (2008) Meeting their potential: the role of education and technology in overcoming disadvantage and disaffection in young people. Retrieved from: http://eprints.lse.ac.uk/4063/1/Meeting_their_potential.pdf

Cranmer, S. (2006). Enhancing graduate employability: Best intentions and mixed outcomes. Studies in Higher Education, 31 (2), 169-184.

European Commission (2004). E-skills for Europe: 2010 and beyond. Brussels: Author.

Harvey, L. (2001). Defining and measuring employability. Quality in Higher Education, 7(2), 97-109.

ILO (2001) Generating decent work for young people: An Issues Paper, prepared for the Secretary-General's Youth Employment Network. Retrieved from: www.un.org/esa/socdev/youthemployment/.

Imouokhome, F. A, Omwangbe, E. S., Ifediora, C. M. (2007). ICTs and their applications to the Nigeria Educational System. Nigeria Journal of Computer Literacy. 8 (1), 1-6.

Kaino, L. M. (2006). Gender attitudes toward Information and communication Technology: A case study of Botswana Junior Schools on the use of computers in learning. African Journals of Educational Studies. 4, 1-14.

Lenhart, A., Madden, M. (2005). Teen Content Creators and Consumers. Washington, DC: Pew Internet and American Life Project.

Litchfield, A., Nettleton, S., Taylor, T. (2008). Integrating work-ready learning into the university curriculum contextualised by profession. Proceedings of the Conference for Work-Integrated Learning: Transforming Futures. October 2008, Sydney Australia.

Lopez-Bassols, V. (2002). ICT skills and employment. Paris: OECD. 
Ogunleye, B. O. (2007). Teachers' Perceived Barriers to Successful Implementation of ICT in the Teaching and Learning of Science Subjects in Nigerian Secondary Schools. Nigeria Journal of Computer Literacy. 8(1), 16.

Rawandale, C. J., Sukhvinder, S., Priyadarshini, S., Pushpa, N. (2013). ICT Method V/S Traditional Method: A Study of Law Students. Prestige International Journal of Management \& IT. 2 (2), 2278-8441.

Sharit, J., Czaja, S. J., Hernandez, M. A., Nair, S. (2009). The employability of older workers as teleworkers: An appraisal of issues and an empirical study. Human Factors in Ergonomics \& Manufacturing. 19, 457-477.

UNESCO (2010). Long distance learning of the Spanish language. Retrieved from: http://www.unesco.org/en/higher-education/higher-education-and-icts/.

UNESCO (2002a). Information and Communication Technologies in Teacher Education: A Planning Guide. Paris: UNESCO.

UNESCO (2002b). Information and Communication Technology in Education. A Curriculum for Schools and Programme for Teacher Development. Retrieved from: http://unesdoc.unesco.org/images/0012/001295/129538e.pdf.

Welsum, W., Vickery, G. (2005). New perspectives of ICT skills and employment. Paris: Organisation for Economic Co-operation and Development.

Yusuf, M. A., Festus, O., Loto, A. B. (2013). Appraising the role of information communication technology (ICT) as a change agent for higher education in Nigeria. International Journal of Educational Administration and Policy Studies. 5 (8), 177-183. 